ORIGINAL ARTICLE

\title{
Beneath the Waves: Experiences of Beginner SCUBA Divers and Sensorium
}

\author{
YALIN AYGÜN 1 , GÖKTUĞ NORMAN² \\ ${ }^{1}$ Department of Sport Management, Faculty of Sport Science, University of Inonu, Malatya, Turkey \\ ${ }^{2}$ Department of Sport Management, Faculty of Sport Science, University of Inonu, Malatya, Turkey \\ Correspondence to: Dr. Yalın Aygün, E-Mail yalin.aygun@inonu.edu.tr, Contact: +905325019144
}

\begin{abstract}
Background: The experience of Recreational SCUBA Diving (RSD) is unique and exciting because participants can feel innermost and special sensations.

Aim: By exploring the role of the senses in RSD This paper seeks to illustrate the complex, kaleidoscopic and inter-relational connections beginner SCUBA divers make with aquatic environment within the sensorium experience for the first time.

Methods: The present research draws upon the qualitative inquiry away from the positivist approaches to capture insider views, meanings, and interpretations. Audio-recorded semi-structured interviews with a convenience sample of 12 undergraduate students who had experienced a first-time SCUBA diving through Discover SCUBA Diving (DSD) Program were transcribed and thematically analyzed. A thematic analysis was performed with the Nvivo 11 Plus software package program.

Results: Analysis illustrated that both positive and negative emotions are experienced due to (a) Diver Dimension of Marine Wildlife Touching, (b) Diver Dimension of Marine Wildlife Viewing, and (c) Diver Dimension of Marine Wildlife Hearing.

Conclusion: The opportunity to experience aquatic environment for the first time during active leisure reflects participants' ability, which offers encouragement, enthusiasm, well-being, and satisfaction. In unravelling the negative diving experience, as experienced by divers, we argue some physical and psychological distress and difficulty arise due to chemical and physical properties of aquatic environment, however.
\end{abstract}

Keywords: Active Leisure, Aquatic, Sensorium, SCUBA Diving, Well-being.

\section{INTRODUCTION}

SCUBA is the acronym for 'Self-Contained Underwater Breathing Apparatus ${ }^{1}$, and its modern use is embedded in the language to describe diving with completely independent of surface supply ${ }^{2}$. RSD is one marine-based leisure-adventure activity and has been seen as a form of marine ecotourism where nature is the foundation for exploration ${ }^{3}$. It is through RSD that participants can explore pristine aquatic ecosystems, vibrant reefs and colourful aquatic creatures or explore ancient shipwrecks. In fact, there is a world of underwater adventure ${ }^{4}$. As a certified diver, one can experience exclusive collections of salt and fresh water, natural and human created water bodies, ancient wrecks, caves or caveren ${ }^{5,6,7}$ from the polar-regions to the tropics and everything in between ${ }^{6}$. However, even in the absence of any certificates, it is possible to experience RSD through various programs (i.e., discover SCUBA diving) after meeting certain health conditions. In this context, this research explores emotions and affects during marine-based leisure-adventure activity, namly Discover SCUBA Diving by examining data collected during interviews with beginner divers.

\section{Literature Review}

\section{Discover SCUBA diving}

While not a SCUBA certification course, DSD (Discover SCUBA diving) course is a quick and easy introduction to what it takes to explore the underwater. To sign up for this course, no prior experience with RSD is necessary, but participants need to be in reasonable physical health. In this program, participants learn how to use SCUBA equipment and key skills, have fun swimming around and exploring, and find out what it's like to breath underwater via a one-day adventure to underwater world?

Sensing aquatic environment via DSD: In DSD, novel and unfamiliar sensory experiences are at the forefront. To understand and express the sensory experiences that divers have, one first needs to know about the physical and chemicals laws governing the aquatic environment ${ }^{8,9,10}$, and the mechanics of underwater ecology, ecosystem, and symbiosis $^{11,12}$.

Divers can feel, hear, see and move outside the water in a normal, familiar, and comfortable manner because they are used to it ${ }^{9}$. However, once under the water, they enter a new environment where the senses are disparately mobilized $^{13}$. Water, which is 800 times denser than air, creates additional pressure, affects the buoyancy of objects, and cause heat, light, and sound to behave particular $8,9,10$.

Aquatic environment can make recreational divers, in particular, to mobilize unusual sensory experiences through bodily touch $14,15,16,17,18$. However, focusing on the sense of touch should not be taken to mean the absence of other sensory experiences ${ }^{19,20,21}$. Sedgwick, for example, notes that the sense of touch, on its own, is not similar to other senses, but is on the boundary between the senses of touch and sight. In fact, beyond sight and touch, other senses such as hearing also participate in the sense of touch $^{22}$. As Paterson explains, this does not mean accepting a multi-sensory state, but recognizing the complexity of the senses as they work together ${ }^{23}$.

The haptic system, which is related to the sense of touch in all its forms, provides insights to discover how the sense of touch is activated as a complex sensory device ${ }^{23,24}$. 
The haptic system records the contact between the body and the environment through pressure on the skin, temperature, and heat. Because this system involves bodily sensations, it goes beyond external contact to some extent, and functions together with an information network consisting of bodily receptors, hair cells, bodily fluids in the vestibular canals (inner ear), and processes known as kinaesthesia $24,25,26$. Kinaesthesia, which involves the sense of movement as felt in muscles, tendons, and joints ${ }^{23,27,28}$ plays an important role in divers' adaptation to the environment, physical integration, and discovery of sensory experiences that are mobilized through contact ${ }^{18,29,30,31,32}$. During the dive, the vestibular system integrates with the sense of buoyancy because it provides bodily orientation, and works with other bodily sensations to keep the diver in balance. Calling attention to the concept of bodily touch requires gaining an understanding of how the body recognizes and integrates with the environment viscerally, unconsciously, and via cognitive means. This understanding can be explained as the set of knowledge and skills required for divers to be able to retain their positions within the fluidity of the silent and moving body of water that surrounds their own bodies ${ }^{26}$.

There are parochial number of studies on divers' integration with matter (physical and chemical properties of water) in a given aquatic environment, the somatic effects of this integration on divers' bodies, and how these effects are mobilized through senses and transformed into experiences $^{14,15,16,17,18}$.

DSD also allows divers to have umpteen special experiences, and has adventure aspects that can be pivotal to the lives of divers in multiple ways. For example, Dobson notes that divers can meet and swim with sharks in their natural habitat as special leisure experience ${ }^{33}$. Todd, Graefe and Mann Compares the motivation of divers with their levels of development, and observes that most participants value the opportunity offered by diving to experience novel situations and to escape daily life ${ }^{34}$. Dimmock argues that diving with acquaintances like family and friends is an indicator of a comfort- and trust-based approach that avoids the element of surprise in the water ${ }^{35}$. Positive emotions and DSD: This article acknowledges that DSD program is unique and exciting because recreational divers gain multi-sensory experiences and new feelings ${ }^{29}$, which may affect emotions positively as a social, cultural and spatial phenomenon ${ }^{16,17,18,35}$. Such reasons often extend into the Broaden-and-Built Theory, which describes the form and function of a subset of positive emotions, involving joy, interest, contentment, pride, and love ${ }^{36,37}$. A key prototypic concept is that these positive emotions broaden an individual's momentary thoughtaction repertoire: joy (sparks the urge to play), interest (sparks the urge to explore), contentment (sparks the urge to savour), pride (sparks the urge to achieve personal growth), and love (sparks a recurring cycle of each of these urges within safe, close relationships) ${ }^{36}$. Furthermore, experience of positive emotions share the ability to build important and lasting physical, intellectual, psychological and social enduring personal resources ${ }^{38}$, which indicate long-term well-being 39,40,41,42.

Positive emotions also can be better understood through a special explanation of well-being within two key opposing philosophical traditions: hedonism and eudemonism ${ }^{43}$. Both traditions are pertinent to happiness, but the hedonic view equates happiness with pleasure, comfort, and enjoyment ${ }^{44}$, whereas the eudemonic view equates happiness with the human ability to pursue complex goals which are meaningful to the individual and society ${ }^{45}$. Within the concept of well-being, a key interest of hedonism is the repairing the worst things in life by building positive qualities in order to gain a high degree of satisfaction of a life worth living ${ }^{36,44}$.

Furthermore, hedonic tradition focuses on maximizing pleasure via sensual experience, subjective well-being, and multi-sensory experiences specifically ${ }^{38}$. The eudemonic tradition, however, draws upon 'virtue' away from hedonic tradition, and upholds that well-being involves more than solely happiness ${ }^{46}$. This tradition, thus, aims a world-wide concept of a life worth living by focusing on one's potential, satisfaction process of full fully, long-term well-being, life goal, personal growth, and psychological well-being ${ }^{45,46}$.

General emotional theories present evidence for a new facet of our understanding of how do beginner SCUBA divers emotionally experience the aquatic environment in the broader context of leisure-adventure. Thus, this research described, conceptualized and tried to explain the divers' engagements with emotions and affects as social, cultural and spatial phenomenon by focusing on their contextual leisure experiences mobilized within the DSD course. To indicate the intellectual and theoretical contributions of the study, WEformulated following research questions based on the comparative puzzle ${ }^{47}$ :

- What is like to experience aquatic environment via DSD course during leisure-adventure?

- What kind of emotional experiences are mobilized disparately in aquatic environment, compared to terrestrial environment?

\section{MATERIAL \& METHODS}

The present research draws upon the qualitative inquiry away from the positivist approaches to capture insider views, meanings, and interpretations ${ }^{48,49,50}$.

Participants: Securing participant for this research involved convenient sampling approach ${ }^{51}$. This approach required two criteria, sufficiency and saturation ${ }^{51,52,53}$. In an effort to fulfil sufficiency criteria, we secured participants merely from non-diver undergraduate students registered to the SCUBA association - a university organization for students. Moreover, each student agreed to participate in this research based on anonymity. Thus, all names of individuals and places were pseudonyms. When saturation began to emerge from the data, however, we made no further efforts to secure participants. Thus, final research group consisted of sixteen males and thirteen females total 12 students with an average of 19.7 years $(S D=.3)$.

\section{Data Generation:}

To take plunge into DSD course and conduct this research, we made a touristic bus vacation with thirty-seven undergraduate students to a regional and metropolitan dive destination along the south-western cost of the Turkey. Upon visiting a local dive resort, each student was given an informed consent form, liability release and assumption of risk agreement statement, and medical questionnaire based on the ethics requirements. 
We generated the data within two phases ${ }^{47}$. In phase one, we adopted participant observer method to gain epistemological privilege by participating in and discovering what is going on before, during, and after the DSD course $^{54}$. Thus, we conceptualized ourselves as active and reflexive participants, and wrote memos point to participants' behaviours and attitudes towards entire process of the DSD course ${ }^{55}$. In phase two, on the other hand, we adopted phenomenological, in-depth interview method to explore the phenomenon under investigation ${ }^{52}$. From this perspective, we reviewed literature, and conducted brief interviews with few SCUBA instructors in line with the research objectives to create amenable unstructured interview guide $49,56,57$. Next, we finalized the interview guide was based on the recommendations and criticisms of the subject-matter experts to conduct more authentic and valid interviews based on naturalistic approach ${ }^{49,57}$. Upon completion of the pilot interviews, the actual interviews were held after participants' first enrolment with the DSD course in the course of 2 days at a local dive resort in Fethiye, Turkey. The average of each interview was 28 minutes.

Prior to dive, first author YA gave fifty-five minutes DSD lesson and they learned the basic safety guidelines and skills needed to RSD under the direct supervision of YA. Within the DSD course, we put participants into groups, and each group included maximum 3 participants. Each dive took approximately twenty-five minutes, and maximum depth was determined as 9 meters.

\section{Analysis}

A thematic analysis through NVivo 11 Plus software package program was conducted through the six phases described by Braun and Clarke and the analysis was as followed ${ }^{58}$ :

- $\quad$ Phase one (familiarizing): We transcribed, read and re-read the data, noting down initial ideas. During this familiarization with the data, notes were jotted down as initial ideas.

- Phase two (generating initial codes): Interesting features of the data were coded in a systematic fashion across the entire data set and data relevant to each code were collected.

- $\quad$ Phase three (searching for themes): Next, we collated codes into potential themes, gathered all data relevant to each potential theme.

- $\quad$ Phase four (reviewing themes): In this phase, we checked if the themes work in relation to the coded extracts (Level 1) and the entire data set (Level 2) (55,59), generated a thematic map of the analysis.

- $\quad$ Phase five (defining and naming themes): Then, we conducted ongoing analysis to refine the specifics of each theme, and the overall story the analysis tells, generated clear definitions and names for each theme.

- $\quad$ Phase six (producing the report): The last phase was included selection of vivid, compelling extract examples,final analysis of selected extracts, relating back of the analysis to the research question and literature, producing a scholarly report of the analysis. We sorted and compared the data and then weaved together with a high degree of agreement (Cohen's K =.82).

\section{RESULTS AND DISCUSSION}

The results in this study offer a description of beginner SCUBA divers' experiences of being immersed in marine locations. Analysis resulted in a synthesis of the various ways both positive and negative emotions are experienced due to (a) Diver Dimension of Marine Wildlife Touching, (b) Diver Dimension of Marine Wildlife Viewing, and (c) Diver Dimension of Marine Wildlife Hearing.

\section{Diver dimension of marine wildlife touching}

Well-being in water was defined in a physical context. Physical well-being during diving was clear in divers' statements about experiences that were effortless and comfortable. Experiences in deep underwater environments with currents resulted in feelings of 'being weightless' due to the difference in resistance against gravity. There was an emphasis on how the ocean is a mysterious place, parts of which are connected to one another through currents and tides, and easily discovering currents with different temperatures through physical integration with the water was described as a unique underwater experience not found in other recreational activities. 'To me, going with the current under the water is like intergalactic travel' (İncir).

The moment I started having an experience during my first five in water with currents, I encountered its emotional aspects. Thus, I was able to feel the excitement of weightlessness and lightness in blue ocean, gliding deep in the water, and this was something I did not encounter in other activities. (Kiraz)

Sedgwick notes that the sense of touch, on its own, is not similar to other senses, but is on the boundary between the senses of touch and sight ${ }^{22}$. In support of this view, a participant emphasized the effortless and comfortable aspects of diving, and compared RSD to "being both the viewer and actor of a movie' (Portakal).

Divers were flourished when movement was easy which allowed them to swim and be supported by the buoyancy and the ocean. Thus, with its currents and swimming transitions, the aquatic environment provides divers with a novel environment for discovering new ways of being in space and traveling. At such times, Saville emphasizes, it is possible for a 're-enchanting of the body in place ${ }^{21}$, where participants offered unrivalled potential to engage with the freedom space has to offer. A historical review of the development of RSD technologies conducted by Diole reports that some divers find it easy, in physical terms, to adapt to new experiences related to RSD ${ }^{60}$. He observes that people who are used to swimming in seawater are 'lithe swimmers underwater'. Merchant mentions that in their ecotourism experiences, divers can glide effortlessly with the current vertically or horizontally, or integrating with the water in any other position underwater $^{29}$. Moore notes that both surfing and SCUBA diving result in a spiritual experience for most participants ${ }^{32}$. Straughan argues that intentional touching under the water, by extending hands and fingers to hold an object, is a very important sensory experience for divers, even though it is perceived to be problematic for underwater ecology ${ }^{18}$.

Try dives conducted in a marine environment produced a wide range of thalassotherapy effects for firsttime divers, which refer to salt water cleansing with 
rejuvenating, relaxing, or invigorating effects. This was about the 'meditational' or 'spiritual' capacity of dives in salt water.

You don't need to keep trying different alternative medicine therapies and spending money by the truckload to cure your body and soul. You can have all of that as part of your vacation plan if you go on a RSD vacation. (Elma)

I like swimming in salt water in general because I believe it relaxes me greatly. After I learned how to dive, I had the opportunity to completely integrate with salt water. In my first SCUBA dive, I was like receiving therapy from a psychologist, and my whole body relaxed. (Kavun)

Thalassotherapy is derived from thalassa, the Greek word for 'sea' 61 , and is based on the systematic use of seawater, seafood products, and the coastal climate as a form of therapy ${ }^{62}$. In thalassotherapy, it is believed that trace elements of magnesium, potassium, calcium, sodium, and iodide in seawater are absorbed through the skin. The therapy is administered in various ways including showering in seawater, applying sea mud or algae paste, and breathing in sea mist ${ }^{63}$. However, the effectiveness of this therapy is not widely accepted because it is not scientifically proven.

For divers, the somatic tensions and pressures they feel inside and around their bodies as a result of the physical and material contact they have with the water environment may be more complicated. A material and physical experience is felt in the body, giving rise to a feeling of space. For example, Casey calls attention to Husserl's idea of kinaesthesia and describes it as 'the inner experience of a resting or moving body as it feels itself moving or passing at a given moment'27. Building upon Husserl's idea, Casey explains that various aspects of place cannot be experienced in the absence of the kinaesthetic sense because it affects perception.

Looking at data on the problematic aspects of RSD, partly arising from physical pressure, a big majority of novice divers who gained some diving experience soon felt the effects of the negative emotional reaction to the underwater environment. Because emotions, thoughts, and physical reactions are intimately connected, participants underlined the negative experiences that they had in their first SCUBA dive, such as worries, fear, and disappointment, and the psychological pressure arising from physical pressure. 'I was learning to do something new, and not everything went as planned. This resulted in some fear and disappointment accompanied with the ear problem I had in the first few minutes after I dived' (Üzüm).

When you are threatened or challenged, you should be able to protect yourself and avoid danger. I think it was because of the pressure, I don't know, but I had a heightened sense of self-protection and avoiding danger in my first dive. (Armut)

I saw that unfamiliar physical conditions such as the pressure in the water had a visible effect on my first dive. It led to a slight loss of control and experiencing challenges that I hadn't faced on the land. (Karpuz)

Merchant notes that first-time divers may dislike internal bodily senses arising from pressure. For example, the stabbing sinus pain that Julian, one of the participants of the study, mentions makes him aware of his brain ${ }^{29}$. Moreover, the conscious, slow, and regular breathing described by Lee shows that he understands how pressure is pushing the boundaries of his lung surface area, a problem related to his inhaling and exhaling volume. Moreover, worry and excitement increase heart rate and change breathing ${ }^{64}$. Stress can affect he most basic diving skills by changing the focus of attention ${ }^{65}$. How one feels under the water can be a direct determinant of the form of diving. In addition to the underwater, life above the surface is full of pressures and distractions ${ }^{66}$, and this can make it really difficult to focus on what is important regarding the RSD experience.

\section{Diver dimension of marine wildlife viewing}

Based on the sense of sight, the underwater was perceived as 'a different planet' with symbioses, the local ecosystem, underwater ecology, aquatic plants, and animal habitats. Divers said that they tended to take a lot of pictures and make video recordings under the water to be able to show non-divers how spectacular the view is and to start a conversation.

Little creatures moving in harmony without touching one another, coral reefs full of colour and life, and algae made feel like I was on another planet. I have to show sincere respect to this planet and its dwellers. You can bet that I will try to immortalize all my dives from now on with pictures and videos so that I can share the magnificence of the underwater with others to achieve that. (Kiraz)

Divers stated that they responded positively to the effects of the colour blue and the widespread "clear water" effect in marine and aquatic environments, and described how these environments increased their well-being and reduced their anxiety. Regular statements such as 'I am always attracted to waters with magnificent views, they make me feel good' (Muz), 'to relax, I usually prefer tropical waters with vibrant and colourful views' (Şeftali), and 'to me, crystal clear water is important' (Mandalina) acknowledge that water clarity creates visual well-being in a SCUBA dive.

Divers flourished when they could easily observe marine creatures in their natural environment. In fact, marine features such as abundant fish life, sharks, rays, dolphins, sea turtles and coral reefs were noted as elements that were part of well-being. 'To me, manta rays are not simply fish; when I watch them feeding under the water, I understand one more time what elegance and freedom mean' (Armut). 'What makes manta rays special is the very special bond you can form with them. It was my first dive and I felt like they understood me, which felt like therapy' (İncir).

Maybe the great white is the big boss of all sharks. Off the coast of Gansbaai, with my adrenaline pumping inside a cage, I felt great predators sliding above my head and watching me with squinted eyes. When you are swimming with them, you feel like other creatures little and insignificant. It looks scary but it is a truly spectacular feeling. (Elma)

Like every underwater enthusiast, I couldn't wait to meet the coral reefs underwater whenever I saw them in documentaries. When I saw thousands-strong schools of fish, the coral reefs, and the large number of tropical fish that gathered around them,

I knew I was right to be enthusiastic. The coral reefs, with their vibrant and colourful appearance, made me 
especially happy. It felt like running around in a flower garden with millions of species. (Erik)

Dolphins were described as 'smart' (Portakal), 'funny' (Üzüm), and 'friendly' (Kavun), and participants said meeting these incredible creatures was one reason why divers tried to create more leisure time and travelled all around the world. 'You can be sure that I will plan my future vacations to have more chances to dive with these lovely creatures [dolphins]' (Mandalina).

It is really difficult to describe the warmth I felt and the smile I had when I saw dolphins' facial expressions. It was like making a new friend. In my future diving career, I will try to go on a vacation with my family every chance I get to meet new dolphins. (Muz)

In a visual context, SCUBA divers described underwater encounters when they were well and flourish with the chance to sight marine fauna and flora. Many comments acknowledged that when water visibility was high divers were satisfied because they could see easily and negotiate with the creatures around the marine site. The desire to meet and swim with underwater creatures seems to trigger the idea of creating more leisure time and making SCUBA-based vacation plans. In a study on divers' satisfaction in Malaysia researchers, divers were found to value visual components of their experiences ${ }^{67}$. Lemelin \& Smale (2006) Lemelin and Smale notes that there are few studies that take the human dimension of viewing wildlife into account ${ }^{68}$. The concept of ocular consumption in wildlife tourism, first used by Lemelin, has temporal, spatial, sensory, and visual dimensions ${ }^{69}$. Underwater ocular consumption has elements of uncertainty and unpredictability, with a unique and exciting potential that can be materialized first-hand through the sense of sight ${ }^{3}$. Kunthea notes that most SCUBA divers tend to materialize their experiences involving the sense of sight by observing the underwater life, seeing rare underwater animate and inanimate formations not seen before, and taking pictures under the water ${ }^{15}$. The SCUBA divers' discussions in this study reflect similar viewing preferences. Most divers had positive things to say about the larger marine species, and divers with specific leisure habits said they would try to create more leisure time and plan their vacations on the basis of their SCUBA habits to have more chances of finding and examining dolphins.

\section{Diver dimension of marine wildlife hearing}

In addition to the senses of sight and touch, hearing underwater was also described as odd and strange. Participants mentioned that the silent aspect of the underwater can contribute, by creating a sense of 'isolation' to leaving behind the pressures or hectic schedules of the daily life. Participants described being underwater as an escape from daily life, and said the silence underwater was an opportunity to be on their own. Overall, the silent character of water was found to have an epochal effect on participants. This was attributed to material integration with an unfamiliar environment and its conditions.

Think about it, there is no trace of the land-based sounds, which used to surround you all the time and you are on your own in a silent, peaceful, completely unfamiliar environment. This aspect of the underwater was what made me feel like I was on another planet, and the silence gave me an incomparable sense of peace. (Üzüm)
People today are looking for ways to get away from the steel and concrete of the city life and find silent places. The underwater, with its complete silence, is an environment where you can be on your own, question things, and re-focus on those aspects of your life that you may be overlooking or missing in the hassle of daily life. (Mandalina)

In addition to the sense of psychological isolation under the water, away from the noise pollution, the sense of belonging that the disabled feel may generate further well-being and flourishing. This lends meaning to Cousteau's description of the ocean as 'A Silent World'70. For example, a participant who partially lost his sense of hearing in a shootout said, after his first diving experience, that he had the advantage under the water, unlike on land, and that he felt like he belonged underwater.

After experiencing hearing loss, I really felt disconnected from the life on land. However, after meeting the underwater, it didn't take me long to decide that this was my new home. This is because everyone, whether hearing disable or not, has to use hand gestures to communicate under the water, and for people like me, mastery of hand gestures is the only way to communicate. I think this is an advantage that I have over others under the water, and supports the idea that underwater is our home. (Erik)

Sounds feel odd and strange under the water because acoustic energy moves four times faster in water compared to air, which turns the underwater into an isolated environment ${ }^{8}$. This property of the sound can allow divers to have "spiritual" and "meditational" experiences under the water ${ }^{29}$; problematically, it also affects the ability to identify the source of sounds, making verbal communication impossible, and due to the viscosity of water, affects the way in which sound waves are transformed into nerve impulses ${ }^{18,71}$. These aspects of water present the diver with an important problem regarding the ability to identify sources of sounds, and sounds are perceived as if they emanate from nowhere. The position of a dive buddy or an object to be avoided becomes a matter of dangerous assumption, with original sounds mixing up with echoes and becoming garbled ${ }^{10,72}$. As the regulator makes a sound every time you exhale, the boats whiz by, dive leaders try to call the attention of groups by hitting their tanks with metal rods or by blowing whistles, all these sounds can cause disorientation and may threaten well-being. Thus, hearing becomes less of a tool for communication, and transforms from an active role to perceiving the ambient noise.

When, in my first dive, I saw creatures I had never seen before in their natural environments and wanted to share this with my friend, I couldn't make myself heard. I tried to do that only by making eye contact and weird sounds. It was really annoying. (Armut)

Understanding words was much more difficult under the water than on land, it was rather impossible. This was why I had to communicate using hand gestures only, which was something I wasn't used to at all. Moreover, as I started to dive, I would be lying if I said I wasn't afraid to hear the engine sounds of the boats above us. How close was I to the propeller of the boat? Could an anchor fall on me? I kept thinking about these things. (Karpuz) 
Participants said that under the water, unlike on land, sounds told divers less about the environment, its dwellers, and their own bodily processes. 'You cannot hear talk, which is interesting, but you also get to experience the working mechanism of your own organs, which is unsettling. How comfortable can you really feel if you keep hearing your heartbeats throughout the dive?' (Portakal). 'I felt and heard my heartbeats more than the environment, which was kind of irritating' (Muz).

Every time I heard the sound of the bubbles when I exhaled, I stopped paying attention to the environment for a while, and focused on myself. However, after I gained some experience in the activity, I stopped doing that and tried to enjoy the environment. (Şeftali)

\section{CONCLUSION}

In this study, We have attempted to contribute to the increasing attention being given to the positive emotions, body, subjectivity and the experiential aspects of leisureadventure activity. By exploring the role of the senses in RSD this paper seeks to illustrate the complex, kaleidoscopic and inter-relational connections divers make with the marine location.

We tried to identify some positive and negative emotions mobilized via immersion in water, by taking into account haptic, ocular and auditory experiences of diving and divers' reflections on the same. For positive emotions, these tend to revolve around well-being, flourishing, and for the hearing disabled in particular, feelings of belonging that they feel underwater but not on land environments. And, as such, they portray, we suggest by way of conclusion, the marine location as what has been termed elsewhere a 'therapeutic', 'meditational' or 'spiritual landscape'. However, in unravelling the negative diving experience, as experienced by beginner divers, we argue some physical and psychological distress and difficulty arise due to chemical and physical properties of water.

\section{Disclosure statement}

No potential conflict of interest was reported by the authors.

\section{REFERENCES}

1. Dimmock K. Scuba diving, snorkelling, and free-diving. In: Jennings $\mathrm{G}$, editor. Waterbased tourism, sport, leisure, and recreation experiences. Amsterdam: Elsevier; 2007. p. 12847.

2. Gwynn M, Laugesen A, Robinson J. The Australian pocket Oxford dictionary. 8th ed. Melbourne: Oxford University Press; 2018.

3. Carter C, Carter E. Marine ecotourism: Between the devil and the deep blue sea. Wallingford: CABI; 2007.

4. Musa G, Dimmock K. Introduction: scuba diving tourism. In: Musa G, Dimmock K, editors. Scuba diving tourism. New York: Routledge; 2013. p. 3-13.

5. Cater C. Perceptions of and interactions with marine environments: Diving attractions from Great Whites to pygmy seahorses. In: Garrod B, S. G, editors. Diving Experiences, Sustainability, Management. Amsterdam: Elsevier Ltd; 2008. p. 49-64.

6. Edney J. Lust for rust wreck divers and the management of underwater cultural heritage. Southern Cross University; 2018.

7. Shreeves K. Adventures in diving. United Kingdom: PADI; 2007.

8. Adolfson J, Berghage T. Perception and performance under water. London: John Wiley \& Sons; 1974.

9. Loske AM. Fundamentals of SCUBA-diving physics. Int $\mathrm{J}$ Sports Sci Coach. 2013;3(2):37-45.

10. Shilling CW, Carlston CB, Mathias RA. The Physician's quide to diving medicine. New York: Plenum; 1984. $768 p$

11. Marion J, Leung Y. Wildland recreation: Ecology and management. In: Hamitt WE, Cole DN, editors. International Impact Research and Management. NY: Wiley; 1998. p. 328-46.

12. Davis D, Harriott V, MacNamara C, Roberts L, Austin S. Conflicts in a marine protected area: Scuba divers, economics, ecology and management in Julian Rocks Aquatic Reserve. Aust Park Recreat. 1995;31(1):29-35.

13. Carter $C$. The life aquatic: Scuba diving and the experiential imperative. Tour Mar Environ. 2008;5(4):233-44.

14. Dimmock K, Wilson E. Risking comfort? The impact of inwater constraints on recreational scuba diving. Ann Leis Res. 2009;12(2):173-94.

15. Kunthea P. Experiences and satisfaction of scuba dive tourists in Cambodia: A case study of Sihanoukville. Auckland University; 2016.

16. Merchant S. The body and the senses: visual methods, videography and the submarine sensorium. Body Soc. 2011;17(1):53-72.

17. Merchant S. Submarine geographies: The body, the senses and the mediation of tourist experience [Internet]. University of Exeter; 2012. Available from: https://ore.exeter.ac.uk/repository/handle/10036/3519

18. Straughan ER. Touched by water: The body in scuba diving. Emot Sp Soc [Internet]. 2012;5(1):19-26. Available from: http://dx.doi.org/10.1016/j.emospa.2010.10.003

19. Colls R. Looking alright, feeling alright: Emotions, sizing and the geographies of women's experiences of clothing consumption. Soc Cult Geogr. 2004;5:108-39.

20. Davidson J, Milligan C. Embodying emotion sensing space: Introducing emotional geographies. Soc Cult Geogr. 2004;5(3):523-32.

21. Saville S. Pakour and the mobility of emotion. Soc Cult Geogr. 2008;9(8):891-914.

22. Sedgwick E. Touching feeling: Affect, pedagogy, performativity. London: Duke University Press; 2003.

23. Paterson M. The senses of touch: Haptics, affects and technologies. Berg: Oxford; 2007.

24. Paterson M. Haptic geographies: Ethnography, haptic knowledge and sensuous dispositions. Prog Hum Geogr. 2009;33(6):766-88.

25. Dixon D, Straughan E. Geographies of touch/touched by geography. Geogr Compass. 2010;4(5):449-549.

26. Obrador-Pons P. A haptic geography of the beach: Naked bodies, vision and touch. Soc Cult Geogr. 2007;8(1):123-41.

27. Casey E. The fate of place: A philosophical history. London: University of California Press; 1998.

28. Gibson J. The senses considered as perceptual systems. Allan G, editor. London: Unwin; 1968.

29. Merchant S. Negotiating underwater space: the sensorium, the body and the practice of scuba-diving. Tour Stud. 2011;11(3):215-34.

30. Fuchs G, Reichel A, Shani A. Scuba divers: The thrill of risk or the search for tranquility. Tour Recreat Res. 2016;41(2):145-56.

31. Kler BK, Tribe J. Flourishing through SCUBA: understanding the pursuits of dive experiences. Tour Mar Environ [Internet]. 2012;8(1):19-32. Available from: http://openurl.ingenta.com/content/xref?genre=article\&issn= 1544-273X\&volume $=8 \&$ issue $=1 \&$ spage $=19$

32. Moore C. Spiritual experiences and environmentalism of recreational users in the marine environment: New Zealand surfers and scuba divers. Lincoln University; 2011.

33. Dobson J. Sharks, wildlife tourism, and state regulation. Tour Mar Environ. 2006;3(1):15-23. 
34. Todd SL, Graefe AR, Mann W. Differences in scuba diver motivations based on level of development. In: Proceedings of the 2001 Northeastern Recreation Research Symposium. The Sagamore on Lake George in Bolton Landing, New York: US Department of Agriculture, Forest Service, Northeastern Research Station; 2001. p. 107.

35. Dimmock K. Finding comfort in adventure: Experiences of recreational SCUBA divers. Leis Stud. 2009;28(3):279-95.

36. Fredrickson BL. The role of positive emotions in positive psychology: The broaden-and-build theory of positive emotions. Am Psyhologist. 2001;56(3):218-26.

37. Fredrickson BL. The broaden-and-build theory of positive emotions. Philos Trans R sciety b Biol Sci [Internet]. 2004;359(1449):1367-77. Available from: http://rstb.royalsocietypublishing.org/cgi/doi/10.1098/rstb.200 4.1512

38. Fredrickson BL. What good are positive emotions? Rev Gen Psychol. 1998;2:300-19.

39. Seligman MEP. Flourish: A visionary new understanding of happiness and well-being. New York: NY: Free Press; 2011.

40. Seligman MEP, Csikszentmihalyi M. Positive Psychology: An introduction. Am Psychol. 2000;55(1):5-14.

41. Peterson C, Park N, Seligman MEP. Orientations to happiness and life satisfaction: the full life versus the empty life. In: Fave AD, editor. The exploration of happiness: present and future perspectives. Netherlands: Springer; 2013. p. 161-73.

42. Schueller SM, Seligman MEP. Differential pursuit of pleasure, engagement, and meaning: relationships to subjective and objective well-being. J Posit Psychol. 2010;5(4):253-63.

43. Ryan RM, Deci EL. On happiness and human potentials: a review of research on hedonic and eudaimonic well-being. Annu Rev Psychol. 2001;52(1):141-66.

44. Diener E, Lucas RE. Personality and subjective well-being. In: Kahneman D, Diener E, Schwarz N, editors. Well-being: The foundations of hedonic psychology. New York: Russell Sage Foundation; 1999. p. 213-29.

45. Delle Fave A, Massimini F, Bassi M. Psychological selection and optimal experience across cultures: Social empowerment through personal growth. 2nd ed. New York: Springer Science \& Business Media; 2011.

46. Deci EL. Ryan RM. Hedonia, eudaimonia, and well-being: An introduction. Stud J Happiness. 2008;9(1):1-11.

47. Mason J. Qualitative researching. 2nd ed. Great Britain: Cromwell Press; 2002.

48. Denzin N, Lincon $\mathrm{Y}$. The sage handbook of qualitative research. 5th ed. London: Sage; 2018.

49. Lincoln YS, Guba EG. Naturalistic inquiry. Beverly Hills, CA: Sage; 1985.

50. Snape D, Spencer L. Qualitative Research Practice A Guide for Social Science Students and Researchers. In: 1. Baskı. London: Sage Publication Ltd; 2003.

51. Patton MQ. Qualitative research \& evaluation methods: Integrating theory and practice. 4th ed. Thousand Oaks, CA: Sage; 2014.

52. Seidman I. Interviewing as qualitative research: A guide for researchers in education and the social sciences. 3rd ed.
New York: Teacher College Press; 2006. 1-162 p.

53. Gorden RL. Basic interviewing skills. USA: F. E. Peacock Publishers Inc; 1992.

54. Denzin NK, Lincoln Y. Sage Handbook of qualitative research. Thousand Oaks, CA: Sage; 2005.

55. Saldaña J. The coding manual for qualitative researchers. London: Sage; 2009. 240 p.

56. Sandelowski M. Whatever happened to qualitative description? Res Nurs Health. 2000;23(4):334-40.

57. Humbert ML, Chad KE, Bruner MW, Spink KS, Muhajarine $\mathrm{N}$, Anderson $\mathrm{KD}$, et al. Using a naturalistic ecological approach to examine the factors influencing youth physical activity across grades 7 to 12 . Heal Educ Behav. 2008;35(2):158-73.

58. Braun V, Clarke V. Using thematic analysis in psychology. Qual Res Psychol. 2006;3(2):77-101.

59. Miles MB, Huberman AM, Saldaña J. Qualitative data analysis: A methods sourcebook. 3th Editio. London: Sage; 2014. $341 \mathrm{p}$

60. Diole P. The undersea adventure. London: Sidgwick and Jackson; 1953.

61. Dictionaries O. Shorter Oxford English Dictionary. 6th ed. Oxford: OU Press; 2007. 1-3743 p.

62. Charlier RH, Chaineux MCP. The healing sea: A sustainable coastal ocean resource: Thalassotherapy. J Coast Res. 2009;838-56.

63. Zijlstra TR, van de Laar MA, Bernelot Moens HJ, Taal, E., Zakraoui L, Rasker JJ. Spa treatment for primary fibromyalgia syndrome: A combination of thalassotherapy, exercise and patient education improves symptoms and quality of life. Rheumatology. 2005;44(4):539-46.

64. Rottenberg JE, Johnson SL. Emotion and psychopathology: bridging affective and clinical science. ABD: American Psychological Association; 2007. 336 p.

65. Everly Jr GS, Lating JM. Personality-guided therapy for posttraumatic stress disorder. ABD: American Psychological Association; 2004. 315 p.

66. Weinberg RS, Daniel G. Foundadion of sport and exercise psychology. 6th Editio. Schrag M, Ewing AS, Gentis CA, Cole A, Eastin AM, editors. USA: Courier Companies; 2015. $443 \mathrm{p}$.

67. Musa G, Sharifah Latifah Syed A. K, Lee L. Layang: An empirical study on scuba diver's satisfaction. Tour Mar Environ. 2006;2(2):89-102.

68. Lemelin RH, Smale B. Effect of environmental context on the experience of polar bear viewers in Churchill, Manitoba. $J$ Ecotourism. 2006;5(3):176-91.

69. Lemelin $\mathrm{RH}$. The gawk, the glance and the gaze: Ocular consumption and polar bear tourism in Churchill, Manitoba, Canada. Curr Issues Tour. 2006;9(6):516-34.

70. Cousteau J. The Silent World. New York: Harper; 1953.

71. Cordellos HC. Aquatic recreation for the blind. Washington: Physical Education and Recreation for the Handicapped; 1976. 1-132 p.

72. Shilling CW, Werts MF, Schandelmeier NR. The underwater handbook: A guide to physiology and performance for the engineer. New York: Plenum Press; 1976. 